\title{
Effect of Storage Ventilation on Bulb Disease of Onion
}

\author{
Mukesh Dabhi ${ }^{*}$, Nagin Patel ${ }^{2}$ \\ ${ }^{1}$ Research Engineer, AICRP on PHET, Processing and Food Engineering Department, College of Agricultural \\ Engineering and Technology, Junagadh Agricultural University, Junagadh, India \\ ${ }^{2}$ Vice Chancellor, Anand Agricultural University, Anand, India \\ Email: mndabhi@jau.in
}

\begin{abstract}
Talaja Red' onion grown in Mahuva Taluka of Bhavnagar district of Gujarat was stored in natural and forced ventilated storage structure to investigate changes in bulb quality and its storability after three months of storage period. Standard procedures were followed in determining the weight loss and assessment of disease of bulbs. Average per cent weight losses were found to be 23.74 and 10.24 percent under natural and forced ventilated storage, respectively. The reduction in percent intensity of black mold in forced ventilated storage varied from 25.15 to 31.48 percent whereas it increased in natural ventilated storage up to 39.01 percent. Soft rot was reduced from 10.79 percent intensity to 3.43 percent intensity under natural and forced ventilated storage, respectively. All the bulbs were infected by black mold in natural ventilated storage whereas 86 percent bulbs were infected in forced ventilated storage. The best results were obtained when onion was stored in forced ventilated storage structure for three months.
\end{abstract}

Keywords: Onion storage, bulb disease, weight loss, black mold, soft rot.

\section{Introduction}

Onion (Allium cepa L.) is an important spice vegetable crop, grown almost all over the country, which is seasonal in production, but required round the year [13]. Onion is liked and valued throughout the world for its characteristic flavour, taste and pungency. Storage is an important aspect of post-harvest management. The main objective of onion storage is to extend their period of availability. The primary purpose of storage is to arrest the metabolic breakdown and microbial deterioration. The onion is low perishable crop, yet considerable deterioration may occur during storage due to rotting, sprouting, and physiological weight loss and storage losses could be as high as $66 \%$ [3]. Hence considerable losses will occur during marketing leading post-harvest diseases [5]. The production of onion in Pakistan is generally surplus and the growers temporarily store their produce in field, under shelters, sheds and rooms under ambient conditions, which increase post-harvest rots and decrease quality [8]. It was reported that during off-season the efficient storage facility for onion plays an important role for the consumers as well as for the producers which ultimately prevents serious losses due to rotting and sprouting [15]. There are different types of storage structures used in different parts of the country. Most of these structures lack in proper ventilation resulting in higher storage losses. The poor aeration and air movement resulted in rise of storage temperature, which in turn adversely affected the product storage physiology and pathology. The natural ventilation existing in the commercial onion storage structures did not remove the heat and moisture from the pile of the onion bulbs stored. This resulted in higher storage losses. The forced air ventilation system has a great scope in reducing the storage losses in case of bulk storage of onion [13].

The storage life of onion is dependent on the cultivar and the storage conditions, together with other factors, including harvest and postharvest management, cultural practices, and weather. Bulb quality influences onion consumer acceptance. It was reported that the predominant fungal pathogens associated with the storage diseases of onions were Aspergillus sp., Penicillium sp. and Fusarium sp. [12]. The highest infected bulbs were found in onions stored in cold room $\left(6^{\circ} \mathrm{C}\right)$ followed by Free floor and Bamboo basket. The lowest infected bulbs were found in onions stored in dried sands followed by net-bag and jute bag. Thus, the fungal diseases in storage are higher in large sized onion bulbs than indigenous small sized onions and in cold room $\left(6^{\circ} \mathrm{C}\right)$ than net-bag or jute bag [7]. In general, practices such as rotation, sanitation, optimum fertilization, preventive chemical applications, harvest timing and proper handling, harvesting, 
and storage are recommended for onion disease management [1]. Keeping the above views in mind, the research work was undertaken with the following objectives.

1. To incorporation of different ventilation system in traditional storage structures.

2. To evaluate the performance of onion structures in terms of pathological diseases.

\section{Materials and Methods}

\subsection{Procurement and Storage}

Well cured Talaja red variety of onion was procured from the farmer's field and stored in natural and forced ventilated storage structure. Sample nets of $500 \mathrm{~g}$ (Approx.) onions were positioned at $1.50 \mathrm{~m}, 0.75 \mathrm{~m}$ and $0.10 \mathrm{~m}$ height approximately from the bottom of bulk in both the storage structures.

\subsection{Determination of Weight Loss}

Initially, sample nets weighed before positioning in the storage and at the end of three months of storage sample nets, collected from natural and forced ventilated storage structure, weighed for determining weight $\operatorname{loss}[2]$.

\subsection{Assessment of Bulb Diseases}

The sample netted bulbs were taken for bulb disease assessment. Disease intensity percent was calculated by using the following formula given by [6]. The disease intensity percent was determined by using nine ratings (eq. 1).

$0=$ No area of bulb infected

$1=1-10$ percent area of bulb infected

$2=11-20$ percent area of bulb infected

$3=21-30$ percent area of bulb infected

$4=31-40$ percent area of bulb infected

$5=41-50$ percent area of bulb infected

$6=51-60$ percent area of bulb infected

$7=61-70$ percent area of bulb infected

$8=71-80$ percent area of bulb infected

$9=80-100$ percent area of bulb infected

$$
\begin{gathered}
\text { Percent disease }=\frac{\text { Sum of all numerical ratings }}{\text { Total no. of bulb assessed }} \times \frac{100}{\text { Max. rating number }} \\
=\frac{\mathrm{n} 0+\mathrm{n} 1+\mathrm{n} 2+\mathrm{n} 3+\ldots}{\mathrm{N}} \times \frac{100}{9}
\end{gathered}
$$

where,

$\mathrm{n}=$ Numerical rating for each bulb in sample net

$\mathrm{N}=$ Total number of bulbs assessed

At the end of two months of storage in natural ventilated storage during the turning of onion the sample nets were collected and bulbs were examined externally by the Pathologist from Vegetable Department of Junagadh Agricultural University for determining the intensity of infection of black mould and soft rot by fungal and bacterial rotting (by visual presence of fungi and bacteria). Similarly, at the end of three months of storage, bulbs were examined from natural and forced ventilated storage.

\subsection{Statistical Analysis}

The data obtained was analyzed statistically to determine statistical significance of treatments. Completely Randomized Design (CRD) was used to test the significance of results [11]. The analysis of variance revealed at significance of $\mathrm{p}<0.05$ level, S.E. and C.D. at $5 \%$ level was mentioned wherever 
required.

\section{Results and Discussion}

\subsection{Effect on Weight Loss}

The weight loss was determined by weighing sample nets of onion at the end of three months of storage under natural and forced ventilated storage. Weight loss of onion sample in top, middle and bottom layers under natural and forced ventilated storages after three months of storage are shown in Figure 1.

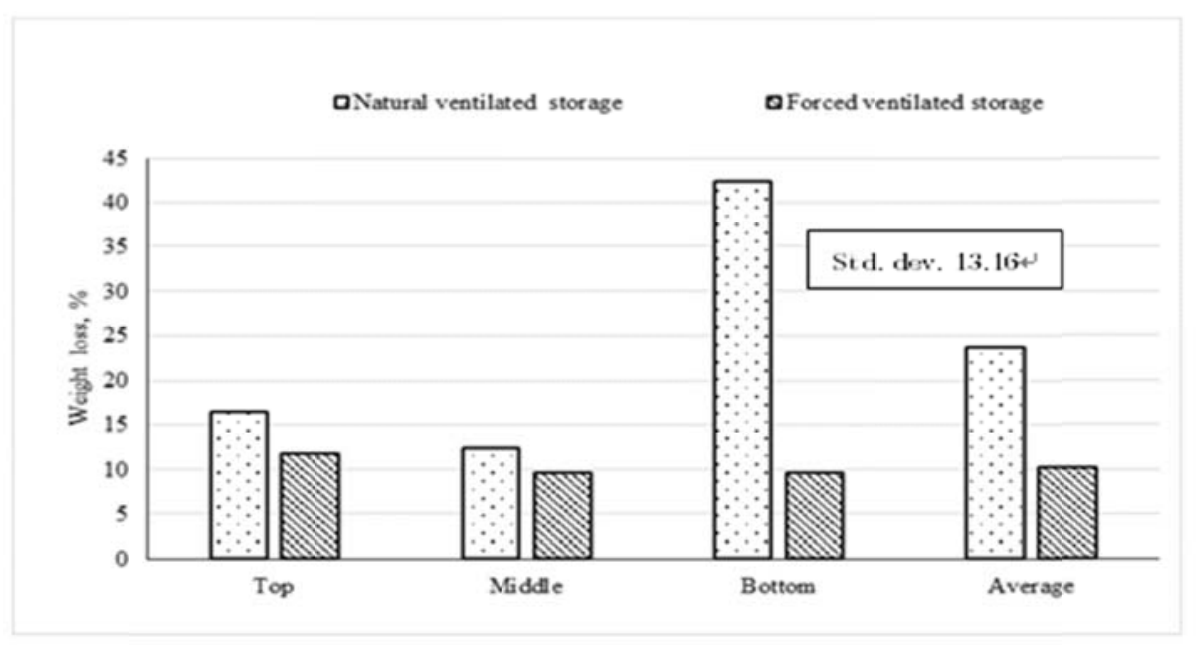

Figure 1. Effect of ventilation on weight loss of onion

At the end of three months of storage period, per cent weight loss in onion sample under natural ventilated storage was 42.44, 12.27 and 16.50 per cent in top, middle and bottom layers, respectively. While under forced ventilated storage structure, it was observed to be 9.49, 9.51 and 11.73 per cent. Average per cent weight losses were 23.74 and 10.24 per cent under natural and forced ventilated storage, respectively. Thus, the infection of Aspergillus Niger onto bulb was also less. ANOVA for effect of storage ventilation on black mould of onion is given in Table 1.

Table 1: ANOVA for effect of storage ventilation on weight loss

\begin{tabular}{l|l|l|l|l|l}
\hline Source & DF & SS & MS & F value & \\
\hline Replication & 3 & 23.96 & 7.99 & 4.33 & $*$ \\
\hline Layer & 2 & 1008.57 & 504.28 & 273.29 & $* *$ \\
\hline Storage period & 1 & 1092.69 & 1092.69 & 592.17 & $* *$ \\
\hline Interaction & 2 & 1140.11 & 570.06 & 308.93 & $* *$ \\
\hline Error & 15 & 27.68 & & 1.85 & \\
\hline Total & 23 & 3293.01 & & & \\
\hline
\end{tabular}

* Significant at $\mathrm{P}<5 \%$ ** Significant at $\mathrm{P}<1 \%$

Further, it was observed that the response of onion sample in top layer under natural ventilated storage was the highest in weight loss which differed significantly from all other onion samples. This was due to the highest rotting and direct effect of atmospheric temperature and relative humidity at top of the storage. Similarly, the weight loss in middle and top layers under forced ventilated was at par. The main effect of layer, storage ventilation and their interaction were highly significant (Table 1). The significance proved that there were real differential effects of storage ventilation with the variation in layer. The effect of fluctuation of temperature and relative humidity under forced ventilated storage structure was less. Hence, 
the weight loss in forced ventilated storage was primarily due to dehydration of the bulbs rather than loss in dry matter or due to sprouting and rotting. It was reported the higher total weight loss at higher temperature [16]. In another study it was also reported greater weight loss after 10, 19, and 31 weeks in traditional storage method than forced ventilated storage bins [4].

\subsection{Effect on Black Mould}

Black mould, caused by Aspergillus Niger, is characterized by black discoloration at the necks of onions. The data of the percent intensity of Aspergillus Niger on onion observed during three months of storage in natural and forced ventilated are shown in Figure 2.

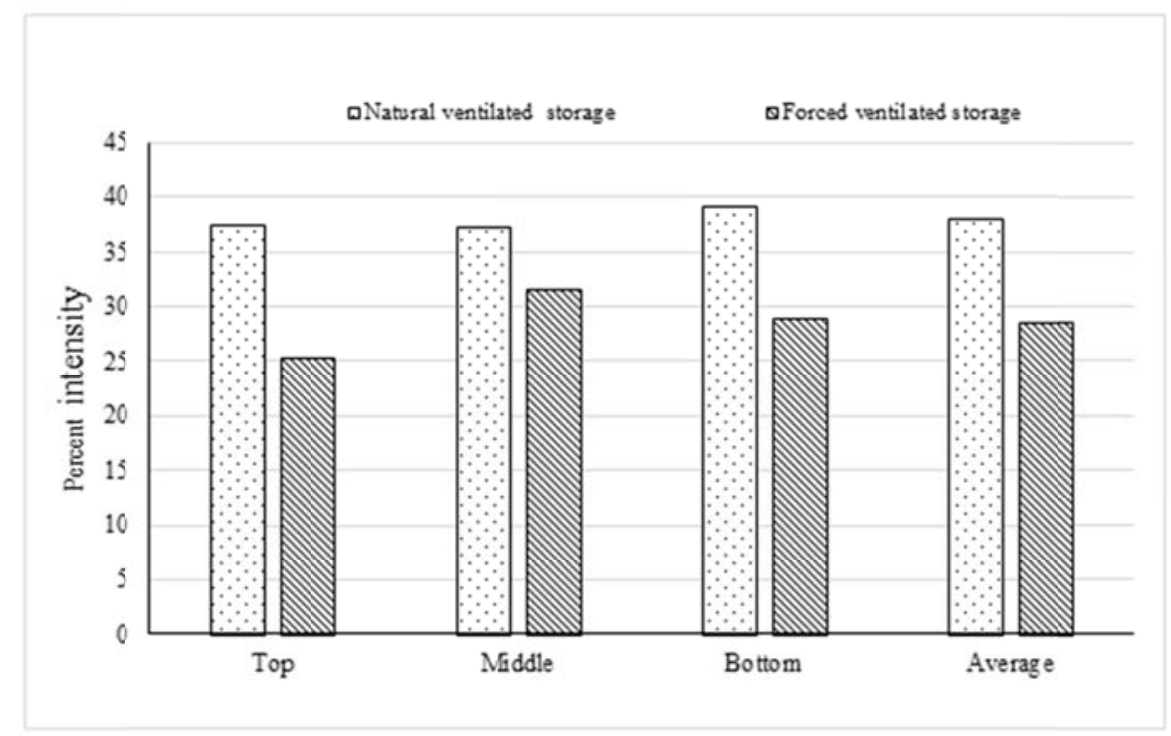

Figure 2. Effect of storage ventilation on black mold

The infection of Aspergillus Niger on onion bulb in natural ventilated storage was higher than the forced ventilated storage. This suggested that there was an effect of ventilation provided by blower in forced ventilation storage. The percentage of bulbs infected in natural ventilation was 100 per cent in all the layers whereas in forced ventilated storage the infected bulbs at top layer was 93.75 per cent and at middle and bottom layer it was 86.10 and 80.00 per cent. Thus, the infection of Aspergillus Nigrer onto bulb was also less. ANOVA for effect of storage ventilation on black mould of onion is given in Table 2 .

Table 2: ANOVA for effect of storage ventilation on black mould

\begin{tabular}{l|l|l|l|l|l}
\hline Source & DF & SS & MS & F value & \\
\hline Replication & 3 & 164.51 & 54.84 & 2.66 & NS \\
\hline Layer & 2 & 45.72 & 22.86 & 1.11 & NS \\
\hline Storage ventilation & 1 & 520.71 & 520.71 & 25.29 & $* *$ \\
\hline Interaction & 2 & 43.68 & 21.84 & 1.06 & NS \\
\hline Error & 15 & 0.19 & 0.10 & & \\
\hline Total & 23 & 9.16 & & & \\
\hline \multicolumn{6}{l}{ Significant at $\mathrm{P}<1 \%$}
\end{tabular}

It was observed that the response to onion sample at bottom layer in natural ventilated storage was the highest in infection, which did not differ significantly from the response of top and middle layer in natural ventilated storage (Table 2). The onion sample at middle, bottom and top layer in forced ventilated storage were also at par. The main effect storage ventilation was highly significant at probability level below 1 per 
cent $(\mathrm{P}<1 \%)$. The significance proved that there was real differential effect due to storage ventilation. The efficacy of six types of containers/methods viz., jute gunny bags, polythene lined gunny bag with perforations, bamboo basket, bamboo bins, wooden rake and hanging method in reducing the spoilage in stored onions. It was reported that containers used for storage of onion bulbs showed significant influence on the incidence and development of Aspergillus niger rot [14]. In another study, it was reported minimum bulbs rots caused by Aspergillus niger in cage and forced ventilated storage of onion [5].

\subsection{Effect on Soft Rot}

The incidence of the heat-resistance spore-forming Erwinia carotovora on onions was probably related to the warm conditions. Soft rot produced B. coagulans and E. caotovaora was evaluated external visually by percent intensity infection to bulbs.

About 1 per cent rotted onions (by weight of initial storage) were removed after two months of storage from natural ventilated storage. Similarly, after three months of storage further, 3.67 per cent rotted onions (totally 4.67 per cent) were removed from natural ventilated storage and 2 per cent rotted onions were removed.

The data of the per cent intensity of soft rot on onion bulbs recorded during two months of storage in natural ventilated storage and three months of storage in natural and forced ventilated storage are shown in Figure 3.

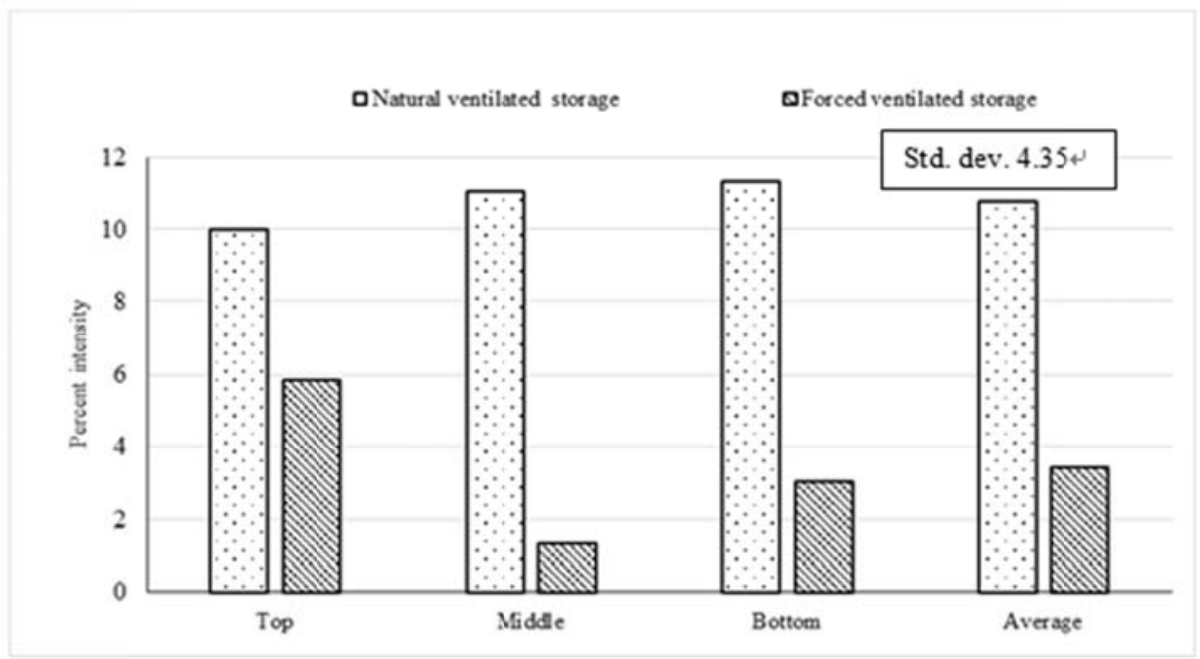

Figure 3. Effect of storage ventilation on soft rot

The infection of soft rot on onion bulb in natural ventilated storage was higher than the forced ventilated storage. This suggested that there was an effect of ventilation provided by blower in forced ventilation storage. ANOVA for effect of storage ventilation on infection by soft rot on onion is given in Table 3 .

Table 3: ANOVA for effect of storage ventilation on infection of soft rot

\begin{tabular}{l|l|r|r|r|l}
\hline Source & DF & \multicolumn{1}{c|}{ SS } & MS & F value & \\
\hline Replication & 3 & 17.59 & 5.86 & 1.48 & NS \\
\hline Layer & 2 & 12.05 & 6.02 & 1.53 & NS \\
\hline Storage ventilation & 1 & 325.24 & 325.24 & 82.37 & $* *$ \\
\hline Interaction & 2 & 33.47 & 16.73 & 4.24 & $*$ \\
\hline Error & 15 & 0.19 & 0.10 & & \\
\hline Total & 23 & 9.16 & & & \\
\hline
\end{tabular}

* Significant at $\mathrm{P}<5 \%$ ** Significant at $\mathrm{P}<1 \%$ 
It was observed that the response to onion sample at bottom layer in natural ventilated storage was the highest in infection, which did not differ significantly from the response of top and middle layer in natural ventilated storage. The onion sample at top and bottom layer in forced ventilated storage was also at par. Similarly, the onion samples at bottom and middle layer were found at par. The main effect of storage ventilation was highly significant at probability level below 1 per cent and the effects of storage ventilation with the variation in layer were at probability level below 5 per cent. The results revealed that there were real differential effect due to storage ventilation and effect of storage ventilation with the variation in layer (Table 3). It is reasonable to get lower and delayed rotting at low temperature [10]. The rotting percentage can be reduced using mud structure that can be locally built under natural ventilation. The percentage of rotting in traditional storage was higher when compared to naturally ventilated bulb onion storage structure $[9,17]$

\section{Conclusions}

Storage life of Talaja Red onion can be increased in forced ventilated storage in order to catch higher market prices. The storage disease in natural ventilation was higher due to sorption and desorption of moisture content. The weight loss can be reduced from 23.74 in natural ventilated storage to 10.24 percent in forced ventilated storage. The storage disease at top was higher due to direct effect of atmosphere to the onion. Modifying the structure with less effect of atmosphere could be solved this problem. Storage disease at bottom and middle was reduced in forced ventilated storage. The profit of onion storage can be increased in forced ventilated storage.

\section{References}

1. Adongo, B. A., C. K. Kwoseh, and E. Moses. 2015. Storage rot fungi and seed-borne pathogens of onion. Journal of Science and Technology, Vol. 35, No. 2, pp: 13-21.

2. AOAC. 1996. Offiicial methods of analysis. Association of Official Analytical Chemists, Washington, USA.

3. Biswas, S.K., A. Khair, P.K. Sarkar and M.S. Alom. 2010. Yield and storability of onion (Allium cepa L.) as affected by varying levels of irrigation. Bangladesh J. Agric. Res., 35:247-255.

4. Brice, J. R.; Bisbrown, A. J. K.; Curd, L. Onion storage trials at high ambient temperatures in the Republic of Yemen. Journal-of-Agricultural-Engineering-Research. 1995, 62: 3, 185-192.

5. Chavan, V. B.; D'-Souza, T. F.; Kokate, S. B.; Sawant, D. M. Efficacy of storage methods for minimizing the bulb rots of onion. Maharashtra-Journal-of-Horticulture. 1992, 6: 1, 73-75.Fatima, N., H. Batool, V. Sultana, J. Ara and S.E. Haque. 2009. Prevalence of post-harvest rot of vegetables and fruits in Karachi, Pakistan. Pak. J. Bot., 41(6): 3185-3190.

6. Maheswari, P., C. Gupta and L. S. Suhag. 1988. A note on the studies of the effect of different fungicides to control Aspergillus rot of onion caused by Aspergillus Niger. Haryana J. Hort. 1-2, 127-129.

7. Mahmud, M. S. and M. S. Monjil. 2015. Storage diseases of onion under variable conditions. Progressive Agriculture 26:45-50.

8. Malenkovic, I. Z., L. M. Djurovka and R. Trajkovic. 2009. The effect of long term storage on quality attributes and storage potentials of different onion cultivars. Acta Hort., (ISHS) 830:635-642.

9. Nabi Ghulam, Abdur Rabi, Muhammad Sajid, Farhatullah, Sayed Jaffar Abbas and Imran Ali. 2013. Influence of curing methods and storage conditions on the post-harvest quality of onion bulbs. Pak. J. Bot., 45(2): 455-460.

10.Nabi, G., A. Rab, S. Jafar, Farhatullah and F. Munsif. 2010. Influence of different levels of potash on the quantity, quality and storage life onion bulbs. Pak. J. Bot., 42: 2151-2163.

11.Panse V. S. and Sukhatme P. V. 1967. Statistical Methods for Agricultural Workers. Indian Council of Agricultural Research. New Delhi. pp: 70-72.

12.Raju K, Nail MK (2006). Effect of pre-harvest spray of fungicides and botanicals on storage diseases of onion. Indian Phytopath., 59 (2): 133-141

13.Roy, Susanta K. and Arun K. Chakrabarti. Post-harvest Management and Processing of onion and Garlic. 2002. 66-72. In Singh, H. P., J. S Mann, U. B. Pandey, Lallan Singh and S. R. Bhonde (Eds.) Onion and Garlic: Production-Utilization NHRDF, Nasik.

14.Srinivasan R, Shanmugam V (2006). Post-harvest management of black mould rot of onion. IndianPhytopath., 59 (3): 333-339. 
15.V. Anbukkarasi, P.Paramaguru L.Pugalendhi, N. Ragupathi and P. Jeyakumar, 2013, Studies on pre and postharvest treatments for extending shelf life in onion A review, Agricultural research communication centre., 34 (4): 256-268.

16.Ward, C. M. The effect of bulb size on the storage-life of onions. Annals-of-Applied-Biology. 1979, 91: 1, 113-117.

17. Wolelaw E., Abaye G., Ayalew D. and Tesfa A. 2014. Storage performance of naturally ventilated structure for onion bulbs. Agric Eng Int: CIGR Journal.16 (3). 